\title{
EFFECT OF DRYING CONDITIONS \\ OF DEHYDRATED LUCERNE ON GROWTH PERFORMANCES OF RABBITS RECEIVING DIETS CONTAINING LUCERNE
}

\author{
F. LEBAS, J. DOLZ* et Annie ESPAIGNET* \\ avec la collaboration technique de Marie-Claude Cousin et G. SARDI \\ Station de Recherches sur l'Élevage des Porcs, \\ Centre national de Recherches zootechniques, I. N.R. A., \\ 78350 Jouy en Josas \\ * Station expérimentale de l'I. T. C. F., \\ 91920 Boigneville
}

In 1972, I 8 different adjustments of the lucerne dehydrating machine have been attempted. They correspond to the factorial combination of 3 factors : the temperature of the air at the inlet $\left(1050^{\circ}-85^{\circ}-650^{\circ}\right)$ and at the outlet $\left(\mathrm{I}_{4} \mathrm{O}^{\circ}-\mathrm{I} 25^{\circ}-\mathrm{I} 10^{\circ}\right)$ as well as the rotation rate of the roller ( 2.8 and $4.8 \mathrm{tr} / \mathrm{mn}$ ). Seven of the lots of lucerne obtained in this way were used to prepare a diet containing 65 p. Ioo lucerne, 32 p. Ioo maize and 3 p. roo minerals and vitamins. Growth performances of rabbits fed these 7 diets were all the better as the outlet temperature of the lucerne dehydrater was low. Neither the inlet temperature nor the rotation rate of the roller seemed to have any striking effect. Comparison of the results obtained with the animals and the chemical analyses of the different lots of lucerne showed that a simultaneous alteration of proteins and carbohydrates was observed in the lots being the least used by the rabbits.

\section{EFFECT OF A LYSINE ADDITION TO SESAME OIL-MEAL DIETS IN THE RABBIT}

\author{
M. COLIN \\ avec la collaboration technique de G. SARDI \\ Station de Recherches sur l'Élevage des Porcs, \\ Centre national de Recherches zootechniques, I. N.R.A., \\ 78350 Jouy en Josas
}

In the rabbit, supplementation of a diet containing $15 \mathrm{p}$. 100 sesame proteins by increasing doses of L-lysine (0-0.225-0.450-0.675-0.900 p. 100) brought about a high improvement of the weight gain and. at a lower scale, of the conversion ratio. The best performances were obtained 